\title{
STUDI PENENTUAN STRUKTUR LAPISAN BATUAN DI DESA PADAELO' KECAMATAN MALLAWA KABUPATEN MAROS SULAWESI SELATAN
}

\author{
Rahmaniah, Hernawati, Nurvadillah, A Fany Aliasra, Irmayanti, dan Ayu Mulia ${ }^{1}$ \\ 1Jurusan Fisika, Fakultas Sains dan Teknologi, UIN Alauddin Makassar \\ Email: nia.physics08.uin@gmail.com, hernawati@uin-alauddin.ac.id
}

\begin{abstract}
It has been done field lecture with the title of study of rock structural layer in the village in the district ELO Mallawa Maros South Sulawesi Regency. The purpose of this field of lecture is to determine the structure of rock lining at the site of field lecture. The methods used in the course of this field are the methods of discussion, sampling and measurement. The tools used are geological compass, meter, hammer geology, GPS and ATK. Results obtained in the location of the lecture field is the presence of production stones consisting of several types of rock layers. The types of rock layers acquired are Rijang stone, sandstone, stone clay, and limestone. And the obtained stone layer has a strike and a dip $\mathrm{N} 353^{\circ} \mathrm{E} 64^{\circ}$.
\end{abstract}

Keywords: Stone, stone structure, color cock.

\section{PENDAHULUAN}

Wilayah Indonesia berada pada pertemuan lempeng - lempeng tektonik aktif yaitu Lempeng Indo-Australia di bagian selatan, Lempeng Eurasia di bagian utara dan Lempeng Pasifik di bagian timur. Lempeng-lempengan tersebut bergerak dan saling bertumbuk sehingga Lempeng Indo-Australia menunjam ke bawah Lempeng Eurasia dan menimbulkan gempa bumi, jalur gunungapi, dan sesar atau patahan, sehingga di Indonesia merupakan zona Ring of Fire (cincin api) dimana terdapat banyak aktifitas seismik yang terdiri dari busur vulkanik dan parit - parit (palung) di dasar laut.

Secara regional, geologi Pulau Sulawesi dan sekitarnya termasuk kompleks karena disebabkan oleh proses divergensi dari ketiga lempeng tektonik yaitu lempeng pasifik yang bergerak ke barat, lempeng australia yang bergerak ke utara dan lempeng eurasia yang bergerak ke selatan - tenggara. Ketiga lempeng tersebut mengakibatkan pulau Sulawesi menjadi tempat berkumpulnya batuan yang terbawa bersama proses tumbukan dan proses tektonik lainnya. Sehingga diindikasikan banyaknya sesar aktif di daerah Sulawesi. Namun setiap struktur lapisan batuan di setiap daerah berbeda - beda. Setiap daerah memiliki struktur sesar, lipatan dan kekar yang berbeda - beda berdasarkan kondisi geologi daerah tersebut.

Struktur lapisan batuan di desa Pada Elo' kecamatan Mallawa kabupaten Maros belum diketahui secara pasti karena belum banyak penelitian ataupun survey yang pernah dilakukan. Jadi kuliah lapangan ini merupakan survey awal sebagai penunjang dilakukannya studi lebih lanjut terhadap struktur lapisan batuan yang ada 
di lokasi tersebut. Maka dari hal-hal tersebut yang melatarbelakangi dilakukannya kuliah lapangan ini.

\section{METODE PENELITIAN}

Kuliah lapangan dilakukan di Desa Pada Elo' Kecamatan Mallawa Kabupaten Maros pada hari rabu tanggal 1 Mei 2019. Secara geografis titik koordinat lokasi kuliah lapangan adalah $4^{\circ} 50^{\prime} 36,19^{\prime \prime}$ LS dan 119 $53^{\prime} 1,02^{\prime \prime}$ BT. Berikut peta lokasi kuliah lapangan.

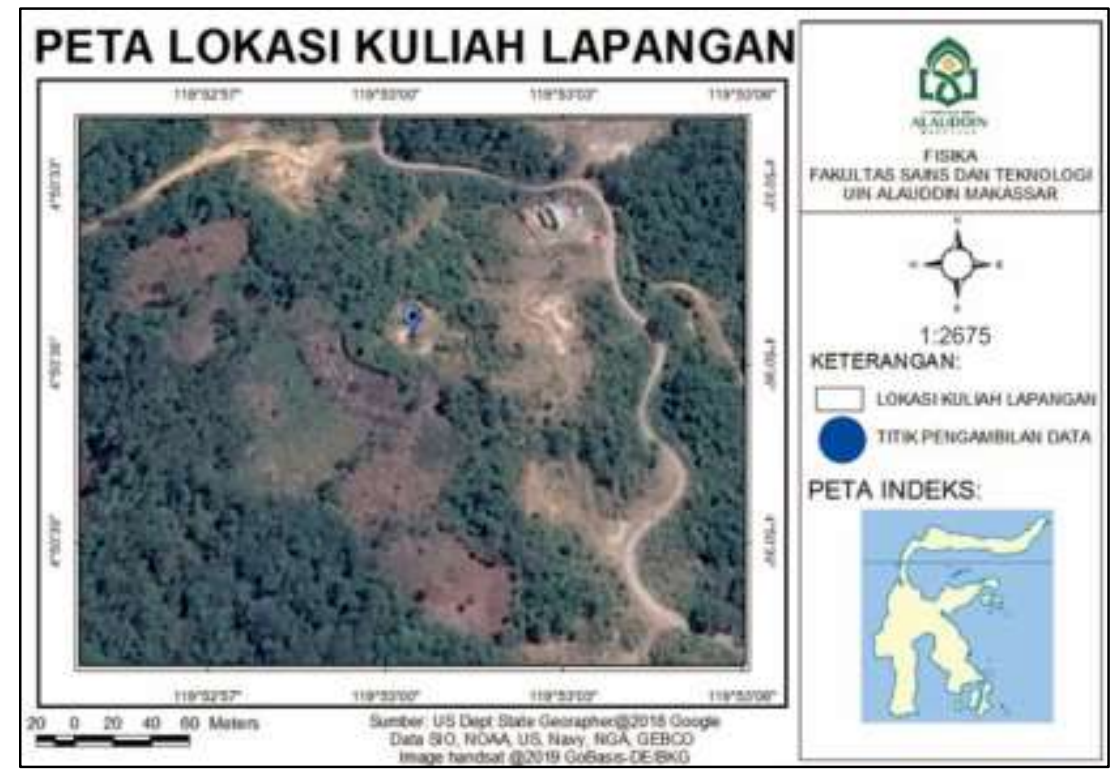

Gambar 1. Lokasi kuliah lapangan

Adapun alat dan bahan yang digunakan dalam kuliah lapangan yaitu kompas geologi, meteran, palu geologi, GPS, dan ATK. Metode yang digunakan dalam kuliah lapangan yaitu sebagai berikut :

a. Mengukur strike dan dip, dimana alat yang digunakan yaitu kompas geologi. Cara untuk mengukur strike yaitu dengan menempelkan sisi $\mathrm{E}$ (east), lalu menggeser - geser hingga gelembung udara dalam bull's eye level masuk ke dalam lingkaran, menunggu hingga jarum kompas stabil dan tidak bergerak dan kemudian mengamati sudut yang ditunjuk arah utara. Sedangkan untuk mengukur dip yaitu dengan cara menempelkan sisi W (west) pada kompas dan mengusakan membentuk sudut $90^{\circ}$ terhadap strike, kemudian memutar clinometer level sampai gelembung udara berada diantara garis dalam clinometer level (ditengahnya). Kemudian membaca sudut dalam skala clinometer.

b. Menggambar sketsa, dimana singkapan yang ada di lokasi kuliah lapangan yaitu menggambarkan sketsa lapisan dan ketebalan batuan.

c. Diskusi kelompok tentang pengelompokan jenis-jenis lapisan batuan berdasarkan warna batuan. Serta menentukan ketebalan setiap lapisan batuan 
dan membandingkan strukutur lapisan yang ada pada lokasi pertama dan kedua. Serta membahas/ mendiskusikan tentang sesar yang ada di lokasi tersebut. Dan terakhir membahas tata cara penggunaan kompas geologi untuk pengukuran strike dan dip.

\section{HASIL DAN PEMBAHASAN}

Struktur geologi daerah Mallawa merupakan salah satu daerah yang memiliki intensitas struktur geologi yang cukup tinggi dan ideal, sehingga dapat dijadikan sebagai tempat pembelajaran geologi, khususnya untuk kajian struktur geologi. Hasil identifikasi yang diperoleh dari kuliah lapangan yaitu gambar struktur lapisan batuan yang terdapat pada lokasi Mallawa kabupaten Maros. Dapat dilihat gambar berikut ini.

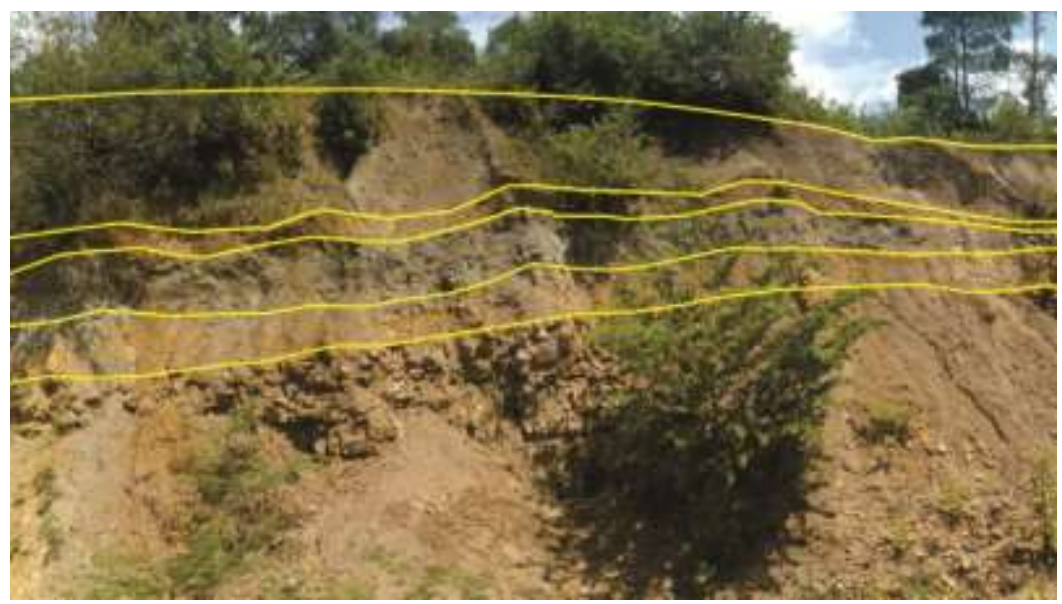

Gambar 2. Model lapisan batuan

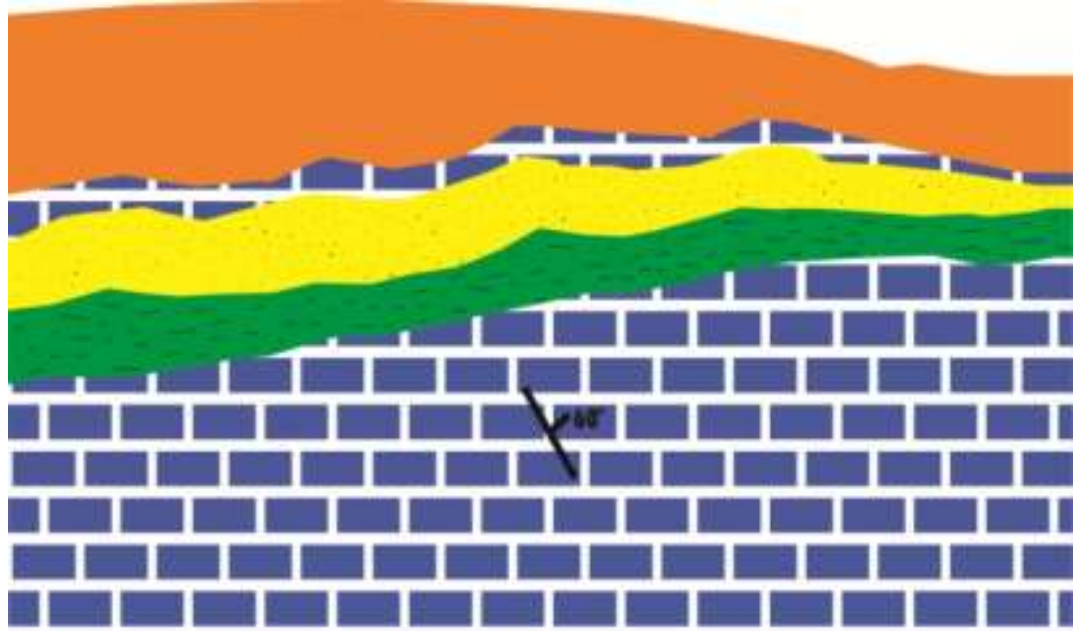

Gambar 3. Kedudukan lapisan batuan 
Lapisan batuan diatas, dapat diidentifikasi bahwa pada lapisan pertama, diduga sebagai baturijang kerana struktur litologi batuannya berwarna merah maroon dan memiliki ketebalan sekitar 1,2 meter. Untuk lapisan kedua, diduga merupakan batugamping karena struktur litologi batuannya berwarna orange kecoklatan dan memiliki kedalaman sekitar 0,2 meter. Untuk lapisan ketiga, diduga sebagai batupasir karena struktur litologi batuannya berwarna abu - abu tua kehitaman dan memiliki tekstur yang agak kasar serta memiliki ketebalan sekitar 0,3 meter. Untuk lapisan keempat merupakan batulempung karena struktur litologi batuannya berwarna abu-abu muda dan memiliki tekstur yang halus dan menempel di jari pada saat dipegang serta memliki ketebalan sekitar 0,3 meter. Untuk lapisan kelima, diduga merupakan batugamping karena struktur litologi batuannya berwarna coklat muda dan memiliki ketebalan sekitar 1,0 meter.

Berdasarkan dari data tersebut yang mengindikasikan gejala struktural yang berupa gawir (tebing curam yang terbentuk akibat sesar dan biasanya disertai perpindahan secara vertikal) karena menurunya lapisan baturijang ke lapisan bawah. Sehingga dapat dianalisis bahwa adanya struktur geologi pada lokasi tersebut berupa sesar (fault) karena memiliki N $353^{\circ} \mathrm{E} 64^{\circ}$.

Jurus lapisan yang dilihat langsung di lapangan, umumnya menunjukkan arah timur dan barat lokasi tersebut terdapat perbedaan lapisan batuan, hal ini dapat diduga bahwa pada lokasi tersebut terdapat struktur sesar. Proses tektonik di bagian barat ini berlangsung dari Kala Trias sampai Miosen Awal. Akhir kegiatan gunungapi Miosen Awal itu diikuti oleh tektonik yang menyebabkan terjadinya permulaan terban Walanae yang kemudian menjadi cekungan tempat pembentuk Formasi Walanae. Menurunnya terban Walanae dibatasi oleh dua sistem sesar normal.

Formasi Walanae berhubungan menjari dengan bagian atas Formasi Camba. Kegiatan gunungapi selama Miosen Akhir sampai Pliosen awal merupakan sumber bahan bagi Formasi Walanae. Kegiatan gunungapi yang masih terjadi di beberapa tempat selama Pliosen, dan menghasilkan batuan gunungapi Parepare. Formasi Wallanae berumur miosen akhir-pliosen, Formasi ini menindih secara tidak selaras dengan batuan gunungapi formasi Camba. Formasi Wallanae tersusun dari perselingan batupasir, konglomerat, tufa dengan sisipan batulanau, batulempung, batugamping, napal dan lignit, batupasir berbutir sedang sampai kasar, umunya gampingan dan agak kompak, berkomposisi sebagian andesit dan sebagian lainnya banyak mengandung kuarsa. Tebal satuan ini diperkirakan sekitar 1.200 meter

\section{KESIMPULAN}

Berdasarkan hasil studi penentuan struktur lapisan batuan, dapat disimpulkan bahwa lokasi kuliah lapangan terdapat singkapan batuan, yang terdiri dari 4 jenis batuan yaitu baturijang, batugamping, batupasir, batulempung. Dan adanya perbedaan lapisan batuan pada lokasi kuliah lapangan yang diakibakan karena adanya struktur atau sesar. Serta Lapisan batuan memiliki strike dan dip N $353^{\circ} \mathrm{E} 64^{\circ}$.

\section{DAFTAR PUSTAKA}

Amin, mustaghfirin, 2014. Geologi dasar semester 1. Jakarta : Kementerian Pendidikan dan Kebudayaan Republik Indonesia. 
Djauhari Noor., 2009. Pengantar Geologi. Jakarta : CV Graha IImu.

Hasan Agung., dkk, 2019. Identifikasi Kekar Desa Pattontongan Kecamatan Mandai Kabupaten Maros, Sulawesi Selatan. Makassar : Universitas Hasanuddin.

Hasanuddin, 2017. Situs Neolitik Mallawa Maros, Sulawesi Selatan (Suatu Hasil Analisis Keterkaitan antara Artefak dengan Sumber Daya Lingkungan. Makassar : Balai Arkeologi Makassar.

http://alfhadlyblog.blogspot.com/2013/11/geologi-regional.html. Diakses pada tanggal 27 Juni 2019 pada jam 16.56 WITA

http://ourgeology.blogspot.com/2010/11/formasi-mallawa.html. Diakses pada tanggal 27 Juni 2019 pada jam 17.16 WITA.

http://thamziz.blogspot.com/2011/11/formasi-batuan-di-sulawesi.html. Diakses pada tanggal 27 Juni 2019 pada jam 17.32 WITA.

Jaya, Wangsa, 2015. Peta geologi. Bandung: ITB.

Sukartomo, 2013. Buku panduan praktikum geologi struktur. Yogyakarta : Sekolah tinggi teknologi nasional.

Warsito Kusumoyudo, 1986. Mineralogi Dasar. Bandung : Bina Cipta. 